\title{
MiR-301a-3p Suppresses Estrogen Signaling by Directly Inhibiting ESR1 in ER $\alpha$ Positive Breast Cancer
}

\author{
Sandra Lettlova ${ }^{a, b}$ Veronika Brynychovac,d Jan Blecha ${ }^{a}$ David Vranac,e \\ Magdalena Vondrusova ${ }^{a}$ Pavel Soucek ${ }^{c, d} \quad J a r o s l a v$ Truksa ${ }^{a}$
}

anstitute of Biotechnology of the Czech Academy of Sciences, BIOCEV Research Center, Prague-West, ${ }^{b}$ Faculty of Science, Charles University, Prague, 'Toxicogenomics Unit, National Institute of Public Health, Prague, dBiomedical Center, Faculty of Medicine in Pilsen, Charles University, eDepartment of Oncology, Palacky University Medical School and Teaching Hospital, Olomouc, Czech Republic

\section{Key Words}

$\mathrm{MiR}-301 \mathrm{a} \cdot \mathrm{ER} \alpha \cdot$ Breast cancer $\bullet$ Estrogen dependence $\cdot$ Estrogen signaling

\begin{abstract}
Background/Aims: MiRNA-301a-3p is an oncogenic miRNA whose expression is associated with tumor development, metastases and overall poor prognosis. Estrogen receptor $\alpha(E R \alpha)$ is one of the estrogen hormone-activated transcription factors, which regulates a large number of genes and is involved in the mammary gland development. Expression of ER $\alpha$ is considered to be a good indicator for endocrine therapy and breast cancer survival. Loss of ER $\alpha$ in breast cancer patients indicates invasiveness and poor prognosis. In this study, we focus on the regulation of $E R \alpha$ by miR-301a and its role in transition from estrogen-dependent to estrogen-independent breast cancer. Methods: Expression of miR-301a-3p was measured by qRT-PCR in tumor tissue samples from 111 patients with primary breast carcinoma and in mammospheres representing in vitro model of cancer stem-like cells. Dual reporter luciferase assay and complementary experiments were performed to validate ESR1 as a direct target of miR-301a-3p. The effect of miR-301a-3p on estrogen signaling was evaluated on the level of gene and protein expression and growth response to estrogens. Finally, the effect of miR301a-3p expression on tumor growth was studied in nude mice. Results: We identified ESR1 as a direct target of miR-301a-3p. Ectopic miR-301a-3p causes a decrease in ESR1 mRNA and protein level and modulates the expression of ER $\alpha$ target genes in ER $\alpha$ positive breast cancer cells. Consistently, miR-301a-3p causes a decrease in sensitivity of MCF7 cells to $17 \beta$-estradiol and inhibits the growth of estrogen dependent tumor in nude mice. Yet, the mice tumors have significantly increased expression of genes related to cancer stem-like cells and epithelial to mesenchymal transition suggesting enrichment of the population of cells with more invasive properties, in line with our observation that miR-301a-3p expression is highly increased in mammospheres which show a decrease in estrogenic signaling. Importantly, miR-301a-3P level


is also increased in primary breast cancer samples exhibiting an ER/PR negative phenotype. Conclusion: Our results confirm ESR1 as a direct target of miR-301a-3p and suggest that miR$301 a-3 p$ likely contributes to development of estrogen independence, which leads to a more invasive phenotype of breast cancer.

(C) 2018 The Author(s)

Published by S. Karger AG, Basel

\section{Introduction}

Breast cancer is the most prevalent type of cancer in women worldwide [1, 2]. Up to $75 \%$ of breast cancer subtypes are estrogen receptor $\alpha(E R \alpha)$ and progesterone receptor (PR) positive. ER $\alpha$ and PR positive tumors are largely well-differentiated, less invasive and are associated with better prognosis in comparison with ER $\alpha$ and PR negative tumors [3-6].

$E R \alpha$ is one of the estradiol $\left(E_{2}\right)$-activated transcription factors, which regulates a large number of genes connected with proliferation, differentiation and migration [7] and plays a critical role in mammary gland biology and development [8]. $\mathrm{E}_{2} / \mathrm{ER} \alpha$ signaling stimulates proliferation of $E R \alpha$ positive breast cancer cells and it is important for the growth of the primary tumor. Furthermore, the expression of ER $\alpha$ negatively correlates with the progressive grade of invasive ductal breast cancer [9]. Moreover, ER $\alpha$ signaling opposes pathways leading to epithelial to mesenchymal transition (EMT) and cancer stem-like cell phenotype $[10,11]$. Thus, expression of $E R \alpha$ is connected with less invasive behavior of breast cancer and is considered to be a good indicator of endocrine therapy and breast cancer survival. This dependency on estrogenic signaling is exploited for treatment with selective estrogen receptor modulators (tamoxifen), selective estrogen receptor down regulators (fulvestrant) or aromatase inhibitors (letrozole) [12, 13]. However, resistance to hormonal therapies connected with transition from hormone-dependent to hormone-independent tumor and metastases formation is the main problem in clinical treatment occurring in almost $40 \%$ cases over 10 years of treatment $[14,15]$.

Until now, multiple mechanisms have been proposed to explain how breast cancer cells escape dependency on estrogen control and acquire hormone-independent, invasive and resistant phenotype. Among them, epigenetic modulation [16], transcription regulation [17], gene mutation [18] and alternative usage of splice variants [19], posttranslational modifications [20] or microRNA deregulation [21] have been described so far.

MicroRNAs (miRNAs) are small, 22 nucleotides long, non-coding RNAs that negatively regulate gene expression by complementary binding to their target mRNAs, which leads to repression of translation and mRNA degradation [22]. They target a wide spectrum of genes and deregulation of their function has important role in cancer progression [23]. MiR-301a-3p has recently emerged as an oncogenic miRNA whose expression is connected with progression and poor prognosis of pancreatic [24], gastric [25], hepatocellular [26], colorectal [27] and breast cancer [28].

In this study, we identified ESR1 mRNA as a direct target of miR-301a-3p and we show that overexpression of miR-301a-3p leads to inhibition of estrogenic signaling in ER $\alpha$ positive breast cancer cell lines. Furthermore, our data suggest an important role of miR301a in a shift from estrogen-dependent to estrogen-independent breast cancer and thus in progression of tumor growth.

\section{Materials and Methods}

Cell lines and transfections

Human breast cancer cell lines ZR-751, MCF7, T47D and BT474 and non-malignant MCF10A cell line were obtained from American Type Culture Collection and were routinely cultivated in Dulbecco's Modified Eagle Medium (Sigma) supplemented with 10\% fetal bovine serum (Thermo Scientific) and 100 $\mathrm{U} / \mathrm{ml}$ penicillin, $100 \mu \mathrm{g} / \mathrm{ml}$ streptomycin; in $5 \% \mathrm{CO}_{2}$ and $37^{\circ} \mathrm{C}$. MCF10A cells were cultivated in DMEM/F12 (Lonza) with $5 \%$ horse serum and $100 \mathrm{U} / \mathrm{ml}$ penicillin, $100 \mu \mathrm{g} / \mathrm{ml}$ streptomycin, supplemented with $0.1 \mathrm{ng} /$ 


\section{Cellular Physiology Cell Physiol Biochem 2018;46:2601-2615 \\ \begin{tabular}{l|l} 
and Biochemistry Published online:May 14, 2018 & $\begin{array}{l}\text { D } 2018 \text { The Author(s). Published by S. Karger AG, Basel } \\
\text { www.karger.com/cpb }\end{array}$
\end{tabular}}

Lettlova et al.: miR-301a-3p Suppresses Estrogen Signaling

$\mathrm{ml}$ cholera toxin, $20 \mathrm{ng} / \mathrm{ml}$ epidermal growth factor (EGF, Thermo Scientific), $0.5 \mu \mathrm{g} / \mathrm{ml}$ hydrocortisone and 1 $\mathrm{mg} / \mathrm{ml}$ insulin. For the generation of mammospheres, the advanced DMEM/F12 medium (Thermo Scientific) supplemented with 5\% proliferation supplement (Stem Cell Technologies), $20 \mathrm{ng} / \mathrm{mL}$ EGF and $5 \mathrm{ng} / \mathrm{mL}$ fibroblast growth factor (FGF, Thermo Scientific), $4 \mu \mathrm{g} / \mathrm{mL}$ heparin (Sigma), $10 \mathrm{mM}$ 4-(2-hydroxyethyl)-1piperazineethanesulfonic acid (HEPES), $1 \mathrm{mM}$ glutamine and 100U/ml penicillin, $100 \mu \mathrm{g} / \mathrm{ml}$ streptomycin was used. The control medium contained 5\% FBS, $10 \mathrm{mM} \mathrm{HEPES,} 1 \mathrm{mM}$ glutamine and 100U/ml penicillin, $100 \mu \mathrm{g} / \mathrm{ml}$ streptomycin. MCF7 cells with inducible expression of miR-301a were prepared by stable transfection with trans-activator coded by pEF1-TET3G vector and with doxycycline-inducible pTREG-IRES vector containing either miR-301a gene or no insert (empty vector, EV), both from Clontech.

\section{DNA constructs}

miR-301a inducible vector

The pri-microRNA-301a sequence was amplified by PCR from cDNA obtained from MCF7 cells using Q5 hot start high-fidelity DNA polymerase (New England BioLabs) with the following primers: Forward 5' CCCTCGTAAAGTCGACTGCATGTTTCTGTTCGAATG; Reverse 5' CAGTTACATTAGATCTGGGCAAGTAACTGCAGGAAA. The amplified sequence was then cloned into the SalI/BglII sites of pTRE3G-IRES vector (Clontech).

\section{Luciferase vectors}

The whole 3'UTR sequence of ESR1 gene was amplified from MCF7 cDNA by using the following primers: Forward 5' TGCAAGTGAGCGGCCGCGAGCTCCCTGGCTCCCACA; Reverse 3' TGCAAGTGAGCGGCCGCTTAGTTTAATTCTTTATTTGAACATC containing the NotI restriction sites. The amplified product was cloned into NotI site of pTK-Cypridina vector (Thermo Scientific). Vectors with deleted first or the second or both sites of predicted miR-301a-3p binding were created by site directed mutagenesis by using Q5 Hot start high-fidelity DNA polymerase (New England BioLabs) according to manufacturer's protocol with the following primers:

Site 1 Forward 5' TTGTTTTCTAAGTAATTGCTGCCTCTGTCTTTTGAGATTCAAGAAAAATTTC;

Site 1 Reverse 5' GAAA-TTTTTCTTGAATCTCAAAAGACAGAGGCAGCAATTACTTAGAAAACAA;

Site 2 Forward 5' CATCCCGC-TGGATTCTTTTTCAATGTTTCATTAAACAAAGCAAAGC;

Site 2 Reverse 5' GCTTTGCTTTGTTTAATGAAACATTGAAAAAGAATCCAGCGGGATG; the thermal conditions for PCR were: $98^{\circ} \mathrm{C}$ for $5 \mathrm{~min}$; 5 cycles of $98^{\circ} \mathrm{C}$ for $15 \mathrm{~s}, 80^{\circ} \mathrm{C}$ for $10 \mathrm{~s}, 70^{\circ} \mathrm{C}$ for $30 \mathrm{~s}$ and final extension at $72^{\circ} \mathrm{C}$ for $8 \mathrm{~min}$ then 15 cycles of $98^{\circ} \mathrm{C}$ for $10 \mathrm{~s}, 80^{\circ} \mathrm{C}$ for $10 \mathrm{~s}$ and $72^{\circ} \mathrm{C}$ for 8 min followed by final extension at $72^{\circ} \mathrm{C}$ for $10 \mathrm{~min}$. Then the PCR reaction was incubated with DpnI Fast digest enzyme (Thermo Scientific) at $37^{\circ} \mathrm{C}$ for 30 min and transformed into TOP10 ultracompetent cells. All constructs were verified by Sanger sequencing (GATC Biotech).

\section{Luciferase Assay}

MCF7, T47D and BT474 cells were transfected with miR-301a-3p mimic (Sigma HMI0442), miR-301a3p anti-miR (Ambion AM17000) and corresponding controls (Sigma HMC0003, Ambion AM17010) using INTERFERin transfection reagent according to manufacturer's protocol (Polyplus). After 24h, the second transfection with luciferase vectors and normalization pTK-Gaussia-Dura Luc vector (Thermo Scientific) was performed using Lipofectamine LTX and Plus Reagent (Thermo Scientific) according to manufacturer's instructions. After $24 \mathrm{~h}$ of incubation, medium was harvested to detect the activities of luciferase using the Pierce Gaussia/Cypridina Glow Assay Kit (Thermo Scientific) using TECAN Infinity (TECAN).

\section{MiR-301 a mimic and anti-miR transfection}

Cells were transfected with $40 \mathrm{nM}$ miR-301a-3p mimic (Sigma HMI0442) or $80 \mathrm{nM}$ miR-301a-3p anti-miR (Ambion AM17000) and corresponding controls (Sigma HMC0003, Ambion AM17010) using INTERFERin (Polyplus) according to manufacturer's instruction. After $72 \mathrm{~h}$ of incubation cells were used for subsequent analysis.

qRT-PCR

The isolation of total RNA from cells was performed by RNAzol reagent (Molecular Research Center) and RNA from mice tumors was isolated by using RNA Blue (Top-Bio) according to manufacturer's protocol. 


\section{Cellular Physiology Cell Physiol Biochem 2018;46:2601-2615 \begin{tabular}{l|l} 
and Biochemistry Published onlıne: May 14, 2018 & $\begin{array}{l}\text { DO } 2018 \text { The Author(s). Published by S. Karger AG, Basel } \\
\text { www.karger.com/cpb }\end{array}$ \\
\hline
\end{tabular} \\ Lettlova et al.: miR-301a-3p Suppresses Estrogen Signaling}

cDNA was synthesized using RevertAid First Strand cDNA Synthesis Kit (Fermentas) using oligo-dT as primers. qRT-PCR was performed using $5 \mathrm{x}$ HOT FIREpol Eva Green qRT-PCR mix (Solis Biodyne). $2.5 \mu \mathrm{L}$ of cDNA containing $10 \mathrm{ng}$ of template RNA was mixed with $5 \mu \mathrm{L}$ of master mix (1.5 $\mu \mathrm{L}$ Eva Green mix, 0.197 $\mu \mathrm{L}$ of $10 \mu \mathrm{M}$ forward and reverse specific primers and $3.3 \mu \mathrm{L}$ of $\mathrm{H}_{2} \mathrm{O}$ ). The thermal profile for qRT-PCR was: $95^{\circ} \mathrm{C}$ for $12 \mathrm{~min}, 38$ cycles of $95^{\circ} \mathrm{C}$ for $10 \mathrm{~s}, 60^{\circ} \mathrm{C}$ for $20 \mathrm{~s}$ and $72^{\circ} \mathrm{C}$ for $20 \mathrm{~s}$. The sequences of primers used are in Table 1. The expression of hsa-miR-301a$3 p$ was assessed using the TaqMan MicroRNA Assay (Applied Biosystems, TM000528); snU6 was used for normalization (Applied Biosystems, TM001973). Hsa-miR-301a-3p was transcribed by RevertAid First Strand cDNA Synthesis Kit (Fermentas) using a specific RT primer. One reaction contained: $3.5 \mu \mathrm{L}$ of RT master mix $(1.5 \mu \mathrm{L} 5 \mathrm{x}$ reaction buffer, $0.095 \mu \mathrm{L}$ RNAse inhibitor, $0.7510 \mathrm{mM}$ dNTPs, $0.5 \mu \mathrm{L}$ Reverse Transcriptase, $0.655 \mu \mathrm{L} \mathrm{H}_{2} \mathrm{O}$ ), $2.5 \mu \mathrm{L}$ RNA of $2 \mathrm{ng} /$ $\mu \mathrm{L}$ concentration and $1.5 \mu \mathrm{L}$ of oligo-dT primers. Thermal profile was: $16^{\circ} \mathrm{C}$ for $30 \mathrm{~min}, 42^{\circ} \mathrm{C}$ for 30 min, and $85^{\circ} \mathrm{C}$ for $5 \mathrm{~min}$. The subsequent qRT-PCR was carried out using HOT FIREpol universal probe mastermix (Solis Biodyne). $1.5 \mu \mathrm{L}$ of $5 \mathrm{x}$ mastermix, $0.375 \mu \mathrm{L}$ of TaqMan assay (20x), $3.125 \mu \mathrm{L}$ of $\mathrm{H}_{2} \mathrm{O}$ and $2.5 \mu \mathrm{L}$ of $5 \mathrm{x}$ diluted cDNA was mixed and run for $95^{\circ} \mathrm{C} 10 \mathrm{~min}$ and 40 cycles of $95^{\circ} \mathrm{C}$ for $15 \mathrm{~s}$ and $60^{\circ} \mathrm{C}$ for 60 s. The data were analysed via GenEx software version 6, reference genes for normalization were identified by Normfinder.

\section{Western blotting}

Harvested cells were washed with phosphate-buffered saline (PBS) and lysed in RIPA buffer. Protein concentration was measured via the Pierce BCA protein Assay Kit (Thermo Scientific). $50 \mu \mathrm{g}$ of total protein was resolved on SDS polyacrylamide gels and blotted onto a nitrocellulose membrane (BioRad). After blocking with 5\% non-fat milk (Serva)/ Tris-buffered saline with $0.05 \%$ Tween-20 (TBS-T) for $1 \mathrm{~h}$, the membrane was incubated overnight in 5\% bovine serum albumin/TBS-T with primary antibody against ER $\alpha$ (sc-544, Santa Cruz), PR (8757S, Cell Signaling), GREB1 (HPA024616, Sigma), Cathepsin D (2284S, Cell Signaling), CXCL12 (3740S, Cell Signaling), BMP7 (ab129156, Abcam), $\beta$-Actin (5125S, Cell Signaling) diluted 1:1000. Next day, the membrane was washed with TBS-T and probed with secondary antibody conjugated with horseradish peroxidase in 1\% milk/TBS-T. The membranes were then washed with TBS-T and incubated with Sirius ECL substrate (Advansta) and chemiluminescence was assessed with LAS4000.

\section{Response of MCF7 cells to estrogen}

The cells were washed several times with PBS and 2500 cells per well were seeded in 96-well plate in $100 \mu \mathrm{L}$ of DMEM media without phenol red (Sigma) supplemented with $10 \%$ charcoal stripped fetal bovine serum (Thermo Scientific) and $100 \mathrm{U} / \mathrm{ml}$ penicillin, $100 \mu \mathrm{g} / \mathrm{ml}$ streptomycin. Cells were incubated with the increasing concentration of $17-\beta-E_{2}$ for 5 days. Cells were then fixed with $4 \%$ paraformaldehyde in PBS and after paraformaldehyde removal, the cells were stained with $0.05 \%$ crystal violet dye (Sigma). The unbound dye was washed away and the bound dye was dissolved in $1 \%$ SDS. The absorbance was measured at 595 nm using TECAN infinity M200 (TECAN).

\section{In vivo experiments}

Female Balb/c nude athymic mice (CAnN.Cg-Foxn $1^{n u} / \mathrm{Crl}$, Charles River) were implanted subcutaneously with $0.72 \mathrm{mg} / 90$-day-release $17 \beta-\mathrm{E}_{2}$ pellet (Innovative Research of America, NE-121) and the following day injected subcutaneously with MCF7 cells inducibly expressing miR-301a or with an EV

\begin{tabular}{|c|c|}
\hline Gene & Primer sequence \\
\hline \multirow[t]{2}{*}{ ESR1 } & Forward: 5'CCGGCTCCGCAAATGCTACGA 3' \\
\hline & Reverse: 5'AGCGGGCTTGGCCAAAGGTT 3' \\
\hline \multirow{2}{*}{ GREB1 } & Forward: 5'GGACCAGCTTCAGTCACCTT 3' \\
\hline & Reverse: 5'CCAAGGGCTACCATTTGGGT 3' \\
\hline \multirow{2}{*}{ PGRA } & Forward: 5'TGGTGTCCTTACCTGTGGGA 3' \\
\hline & Reverse: $5^{\prime}$ CCAGCCTGACAGCACTTTCT $3^{\prime}$ \\
\hline \multirow{2}{*}{ BMP7 } & Forward: 5'ACAAGGCCGTCTTCAGTACC $3^{\prime}$ \\
\hline & Reverse: 5'GGTAGCGTGGGTGGAAGAAT 3' \\
\hline \multirow[b]{2}{*}{ CTSD } & Forward: 5'CTGGACATCGCTTGCTGGAT $3^{\prime}$ \\
\hline & Reverse: 5'TGCCTCTCCACTTTGACACC 3“ \\
\hline \multirow{2}{*}{ CXCL12 } & Forward: 5'GTGCCCTTCAGATTGTAGCCC 3' \\
\hline & Reverse: 5'GCCCTTCCCTAACACTGGTT 3' \\
\hline \multirow{2}{*}{ HER2 } & Forward: 5' CACCCAAGTGTGCACCGGCA $3^{\prime}$ \\
\hline & Reverse: $5^{\prime}$ GCACGTAGCCCTGCACCTCC $3^{\prime}$ \\
\hline \multirow{2}{*}{ CD44 } & Forward: 5' GCTGACCTCTGCAAGGCTTTCAATAG 3' \\
\hline & Reverse: 5’ CTTCTTCGACTGTTGACTGCAATGCA 3' \\
\hline \multirow{2}{*}{ ABCG2 } & Forward: 5'TCGTTATTAGATGTCTTAGCTGCAA 3' \\
\hline & Reverse: 5'TTGTACCACGTAACCTGAATTACA 3' \\
\hline \multirow{2}{*}{ ALDH1 } & Forward: 5' ATGCTTCCGAGAGGGGGCGA $3^{\prime}$ \\
\hline & Reverse: 5' CCCAACCTGCACAGTAGCGCA 3' \\
\hline \multirow{2}{*}{ VIMENTIN } & Forward: 5' GCGACAACCTGGCCGAGGAC 3' \\
\hline & Reverse: $5^{\prime}$ GGTCAAGACGTGCCAGAGACGC $3^{\prime}$ \\
\hline \multirow{2}{*}{ VEGFA } & Forward: 5' AGGGCAGAATCATCACGAAGTG 3' \\
\hline & Reverse: 5’ ATGTACTCGATCTCATCAGGGTACTC 3’ \\
\hline \multirow{2}{*}{ POLR2A } & Forward: 5' TGCTCCGTATTCGCATCATGAACA 3' \\
\hline & Reverse: $5^{\prime}$ ATCTGTCAGCATGTTGGACTCGATG $3^{\prime}$ \\
\hline \multirow{2}{*}{ TBP } & Forward: 5' TGTATCCACAGTGAATCTTGGTTGTAAA $3{ }^{\prime}$ \\
\hline & Reverse: $5^{\prime}$ CGTGGCTCTCTTATCCTCATGATTAC 3' \\
\hline \multirow{2}{*}{ P0 } & Forward: 5' ATCACAGAGGAAACTCTGCATTCTCG 3' \\
\hline & Reverse: 5' GATAGAATGGGGTACTGATGCAACAGTT 3 \\
\hline \multirow{2}{*}{ ZEB1 } & Forward: 5' AACCCAACTTGAACGTCACA 3' \\
\hline & Reverse: 5' ATTACACCCAGACTGCGTCA 3' \\
\hline \multirow{2}{*}{ ZEB2 } & Forward: 5' TGCCCAACCATGAGTCCTCCCC $3^{\prime}$ \\
\hline & Reverse: $5^{\prime}$ CGGTCTGGATCGTGGCTTCTGG 3' \\
\hline
\end{tabular}




\section{Cellular Physiology Cell Physiol Biochem 2018;46:2601-2615 \begin{tabular}{l|l|l} 
and Biochemistry 10.1159/000489687 & $\begin{array}{l}\text { ( ) 2018 The Author(s). Published by S. Karger AG, Basel } \\
\text { www.karger.com/cpb }\end{array}$
\end{tabular} \\ Lettlova et al.: miR-301a-3p Suppresses Estrogen Signaling}

at $2 \times 10^{6}$ cells per animal ( 4 mice per group and experiment was repeated twice). Mice were given doxycycline diet $(200 \mathrm{mg} / \mathrm{kg}$, Bio-Serv) and the tumor growth was monitored twice a week, quantified by ultrasound imaging instrument Vevo770 (Visual Sonics). Mice were then sacrificed and tumors taken for further analysis (measurement of gene and protein expression by qRT-PCR and western blot). All animal studies were approved by Czech Academy of Sciences and conducted in accordance with Czech Council guidelines for the Care and Use of Animals in Research and Teaching.

\section{Patient samples}

Fresh frozen tumor tissue samples were obtained from total 111 patients with primary breast carcinoma diagnosed at the Motol University Hospital (Prague, Czech Republic), the Hospital Atlas (Zlin, Czech Republic), and the Faculty Hospital Kralovske Vinohrady (Prague, Czech Republic) between 2003 and 2014. Processing of the tissue samples was described in detail previously [29]. Histological classification of carcinomas was performed according to standard diagnostic procedures [30]. Expression of ER and PR was assessed immunohistochemically with the $1 \%$ cut-off value for classification of tumors as hormone receptor positive. ERBB2 (OMIM:164870) status was defined as positive in samples with immunohistochemical score $2+$ or $3+$ confirmed by fluorescence in situ hybridization (FISH) or silver in situ hybridization (SISH) analysis. Clinical characteristics of studied breast carcinoma patients are described in Table 2.

The expression level of hsa-miR-301a-3p and reference gene was assessed in patient samples by qRTPCR as described above.

All patients were informed about the study and those who agreed and signed an informed consent participated in the study. The study was approved by the Ethical Commission of the National Institute of Public Health in Prague. The methods were carried out in accordance with guidelines approved by the above Ethical Commission.

\section{Statistics}

Results are represented as mean values \pm S.E.M from at least three independent experiments. The Student's t-test was used to calculate the difference between groups and $\mathrm{P}<0.05$ was considered statistically significant.

\section{Results}

MiR-301a-3p is highly expressed in the in vitro model of cancer stem-like cells that show inhibition of estrogen signaling

There is increasing evidence that invasive properties of breast cancer rely on reprogramming of cancer cells into cancer stem-like cells [31], and recent studies suggest that miR-301a-3p contributes to EMT [32]. In order to better characterize the role of miR-301a$3 p$ in cancer stem-like cells, we assessed the expression level of miR-301a-3p by TaqMan assay in our model of cancer stem-like cells based on growing cells as mammospheres in
Table 2. Clinical characteristics of studied breast carcinoma patients

\begin{tabular}{|c|c|}
\hline Characteristics & Number of patients (\%) \\
\hline \multicolumn{2}{|l|}{ Menopausal status } \\
\hline premenopausal & $12(10.8)$ \\
\hline postmenopausal & $93(83.8)$ \\
\hline not available & $6(5.4)$ \\
\hline \multicolumn{2}{|l|}{ Histological type } \\
\hline invasive ductal carcinoma & $111(100)$ \\
\hline Tumor size, median \pm S.D., $\mathrm{mm}$ & $18.5 \pm 9.8$ \\
\hline \multicolumn{2}{|l|}{ Lymph node metastasis } \\
\hline positive (pN1-3) & $40(36.0)$ \\
\hline negative $(\mathrm{pN} 0)$ & $60(54.1)$ \\
\hline not determined $(\mathrm{pNx})$ & $11(9.9)$ \\
\hline \multicolumn{2}{|l|}{ Pathological stage } \\
\hline I & $39(35.2)$ \\
\hline II & $50(45.0)$ \\
\hline III & $11(9.9)$ \\
\hline not available & $11(9.9)$ \\
\hline \multicolumn{2}{|l|}{ Histological grade } \\
\hline G1 & $17(15.3)$ \\
\hline G2 & $54(48.6)$ \\
\hline G3 & $40(36.0)$ \\
\hline \multicolumn{2}{|l|}{ Estrogen receptor expression } \\
\hline positive & $55(49.5)$ \\
\hline negative & $56(50.5)$ \\
\hline \multicolumn{2}{|l|}{ Progesterone receptor expression } \\
\hline positive & $55(49.5)$ \\
\hline negative & $56(50.5)$ \\
\hline \multicolumn{2}{|l|}{ HER2 expression } \\
\hline positive & $46(41.4)$ \\
\hline negative & $65(58.6)$ \\
\hline \multicolumn{2}{|l|}{ Pathological subgroup } \\
\hline $\mathrm{ER}+, \mathrm{PR}+, \mathrm{ERBB} 2+$ & $22(19.8)$ \\
\hline $\mathrm{ER}+, \mathrm{PR}+, \mathrm{ERBB} 2-$ & 33 (29.7) \\
\hline ER-, PR-, ERBB2+ & $24(21.6)$ \\
\hline ER-, PR-, ERBB2- & 32 (28.8) \\
\hline
\end{tabular}


serum-free medium supplemented with EGF and FGF [33]. We generated mammospheres from several ER $\alpha$ positive breast cancer cell lines (ZR-751, MCF7, T-47D and BT474) and compared miR-301a-3p level between spheres and control adherent cells. We also included non-malignant MCF10A cell line of breast origin as a control representing normal breast epithelial cells. We detected significantly higher miR-301a-3p expression in sphere cells compared to control adherent cells in 3 of the tested cell lines (Fig. 1A). There was no difference between BT-474 control adherent cells and spheres which can be explained by already very high level of miR-301a-3p in adherent BT-474 cells in comparison with other tested adherent cell lines.

We further analyzed the estrogen signaling in the adherent cells and mammospheres derived from MCF7 cells. We detected a profound inhibition of ER signaling in spheres, as documented by western blot analysis showing a significant decrease in the ER $\alpha$ protein level and also a decrease in the amount of the ER $\alpha$-regulated proteins such as Progesterone receptor (PR) and Growth regulation by estrogen in breast cancer 1 (GREB1) expression (Fig. 1B).

Collectively, our data suggest upregulation of miR-301a-3p in cells growing as mammospheres that represent an in vitro model of cancer stem-like cells. Importantly, these cells show a clear inhibition of estrogen signaling in our model, in accordance with published results [34].

Functional miR-301a-3p seed sequences are present in the 3'UTR of ESR1 mRNA coding for $E R \alpha$

In order to assess the importance of the miR-301a-3p in the ER $\alpha$ signaling, we searched for a "seed" sequence within the ESR1 mRNA encoding ER $\alpha$ protein. Using three different publicly available miRNA databases (MiRanda, TargetScan, miRBase) we found that two miR-301a-3p seed sequences are present in the 3'UTR of ESR1 mRNA (Fig. 2A).

To verify the prediction that miR-301a-3p negatively regulates ER $\alpha$ expression through binding to the 3'UTR of ESR1 mRNA, we cloned a 4Kb long 3'UTR of the ESR1 mRNA (containing 2 putative miR-301a-3p binding sites) downstream of the Cypridina luciferase gene in a reporter plasmid system. The reporter plasmid was transfected into MCF7 cells together with miR-301a-3p mimic and miR-301a-3p anti-miR and corresponding control mimic and anti-miR. The luciferase activity assay showed a significant reduction in luciferase activity in cells transfected with miR-301a-3p mimic and conversely significant increase of luciferase activity in cells transfected with miR-301a-3p anti-miR (Fig. 2B). Moreover, we did not detect any changes in luciferase activity when reporter plasmid with deleted miR-301a-3p binding sites was used (Fig. 2B). To determine which miR-301a$3 p$ binding site is more important for regulation of $\mathrm{ER} \alpha$ protein expression,

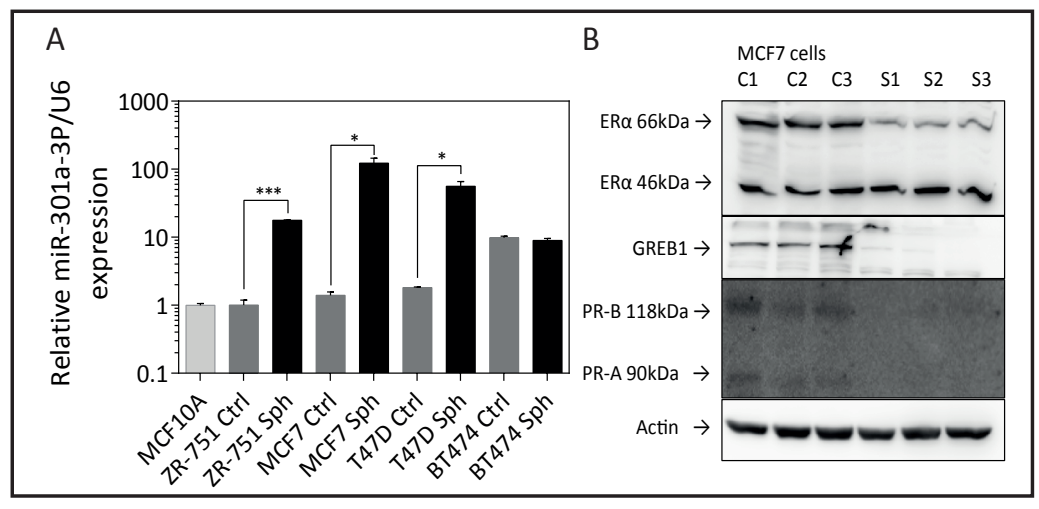

Fig. 1. MiR-301a-3p is highly upregulated in cancer stem-like cells with downregulated ER signaling. A, qRT-PCR was used to measure expression of miR-301a in different cell lines cultivated as mammospheres (Sph) and normal adherent cells (Ctrl). B, Western blot showing decreased expression of ER $\alpha$, GREB1 and PR proteins in MCF7 control adherent cells and mammospheres. Results are represented as mean values \pm S.E.M. $(n=3)$. Statistical significance was calculated using the t-test, where the values obtained from the mammospheres were compared to the control values; ${ }^{*} \mathrm{p}<0.05$, ${ }^{* * *} \mathrm{p}<0.001$. 
Fig. 2. ESR1 gene is a direct target of miR-301a-3p. A, Schematic diagram of miR-301a binding sites in the ESR1 3'UTR. Cypridina luciferase reporter vectors containing the wild type (WT), deleted first, second or both (DEL1, DEL2, DEL1+2) putative target sites in the 3'UTR of ESR1 mRNA were generated. B, Relative luciferase activity of 3'UTR ESR1 WT and DEL1+2 in MCF7 cells transfected with miR-301a and control mimic and miR-301a and control anti-miR. C, Relative luciferase activity of 3'UTR ESR1 WT, DEL1, DEL2 and DEL1+2 in MCF7, BT474 and T47D cells. D, qRT-PCR showing miR-301a expression after transfection with miR-301a mimic and miR-301a anti-miR and expression of ESR1 gene in MCF7, BT474 and T47D cells after transfection with miR-301a mimic and miR-301a anti-miR. E, Representative western blot showing expression of ER $\alpha$ protein in MCF7, BT474 and T47D cells after transfection with miR-301a mimic and miR-301a anti-miR and densitometry evaluation by image J shown at the bottom of panel E. Results are represented as mean values \pm S.E.M. $(n=3)$. Statistical significance was

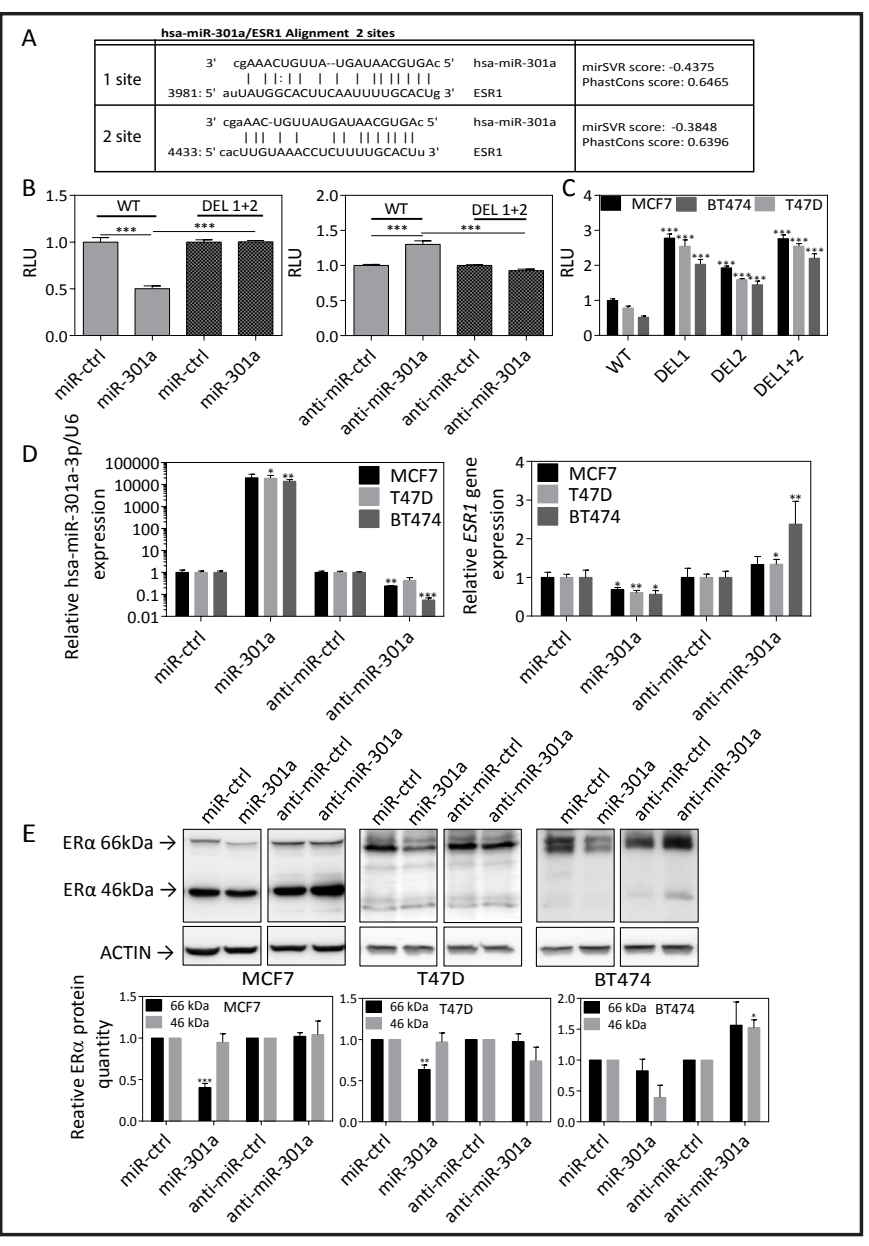
calculated using the t-test; * $\mathrm{p}<0.05, * *$ $\mathrm{p}<0.01,{ }^{* * *} \mathrm{p}<0.001$.

we constructed vectors with deleted first, second or both miR-301a-3p binding sites and transfected them into the MCF7, BT474 and T47D cells. We detected an increase in luciferase activity in both deletions meaning both sites can bind miR-301a-3p. However, the first site is more crucial given the fact that the increase in luciferase activity is almost identical when one or both sites are deleted while the deletion of the second motif only leads to a partial increase in luciferase activity (Fig. 2C).

\section{MiR-301a-3p decreases abundance of ESR1 mRNA and reduces ER $\alpha$ protein level}

In order to confirm the biological relevance of miR-301a-3p in the regulation of ESR1, we analyzed the effect of ectopic miR-301a-3p expression on the abundance of ESR1 mRNA and also ER $\alpha$ protein. High expression of miR-301a-3p resulted in a significant decrease in ESR1 mRNA level in MCF7, T47D and BT-474 cells as assessed by qRT-PCR (Fig. 2D). Also, $\mathrm{ER} \alpha$ protein level tested by western blotting was significantly reduced in MCF7 and T47D cells, in BT474 cells the trend was similar but not statistically significant (Fig. 2E). Our data also show that the effect of downregulation of miR301a-3p by anti-miR was limited and was significant only in BT474 cells which is in line with the fact that these cells express significantly higher endogenous level of miR-301a-3p (Fig. 1A) and the downregulation was the most effective in this particular cell line.

In conclusion, our findings demonstrate that miR-301a-3p recognizes and binds to the 3'UTR of ESR1 mRNA to suppress its translation and mRNA level. 
MiR-301a-3p mimic downregulate the canonical ER pathway as evidenced by inhibition of genes positively regulated by ER $\alpha$ and activation of genes negatively regulated by ER $\alpha$

$\mathrm{ER} \alpha$ is a ligand-activated transcription factor that regulates expression of many target genes [35]. We assessed the expression level of several genes which are positively or negatively regulated by ER $\alpha$ transcription factor in MCF7, T47D and BT474 cells transfected with miR-301a-3p mimic and miR-301a-3p anti-miR and corresponding control RNAs. We found that increased expression of miR-301a-3p leads to a significant decrease in mRNA expression of ER $\alpha$ positively regulated genes as PGRA (Progesterone receptor $\alpha$ ), GREB1 (Growth regulation by estrogen in breast cancer 1), CXCL12 (C-x-c motif chemokine ligand 12) or CSTD (Cathepsin D) or to a significant increase in BMP7 (Bone morphogenetic protein 7) which is negatively regulated by $\mathrm{ER} \alpha$ (Fig. 3A). The changes in expression of these genes were also replicated on protein level (Fig. 3B, Fig. 4).

The effect of anti-miR-301a-3p treatment on ER $\alpha$ signaling pathway was significant only in the BT474 cells. As mentioned earlier, this cells line exhibits high basal expression of miR301a-3p and the effect of anti-miR-301a-3p treatment was thus most evident there, resulting in significant upregulation of the ESR1 mRNA and ER $\alpha$ level (Fig. 2D, E), accompanied by statistically significant increase in the mRNA transcripts regulated by the ER $\alpha$ such as GREB1, PGRA, CXCL12 reflected in the accumulation of the corresponding proteins (Fig 3A, Fig. 4).

Similar trend could also be seen in MCF7 and T47D cells but did not reach statistical significance and was weaker compared to BT-474 cells (Fig. 3B, Fig. 4). It might be explained by the fact that both MCF7 and T47D cells express relatively low levels of endogenous miR-301a and the effect of anti-miR301a-3P treatment is thus limited compared to the BT474 cells.

In summary, our results show that miR-301a-3p regulates the activity of the ER pathway.

Upregulation of $\mathrm{miR}$ 301a-3p level in MCF7 cell line leads to a blunted response to $17-\beta$ estradiol

MCF7 cells transfected with miR-301a-3p mimic and anti-miR and corresponding controls were seeded in 96-well and cell number in estrogenfree medium as well as in the presence of increasing concentrations of 17- $\beta E_{2}$ was measured by crystal violet assay [36]. MCF7 cells transfected with miR-301a3p mimic show significantly lower number of cells in

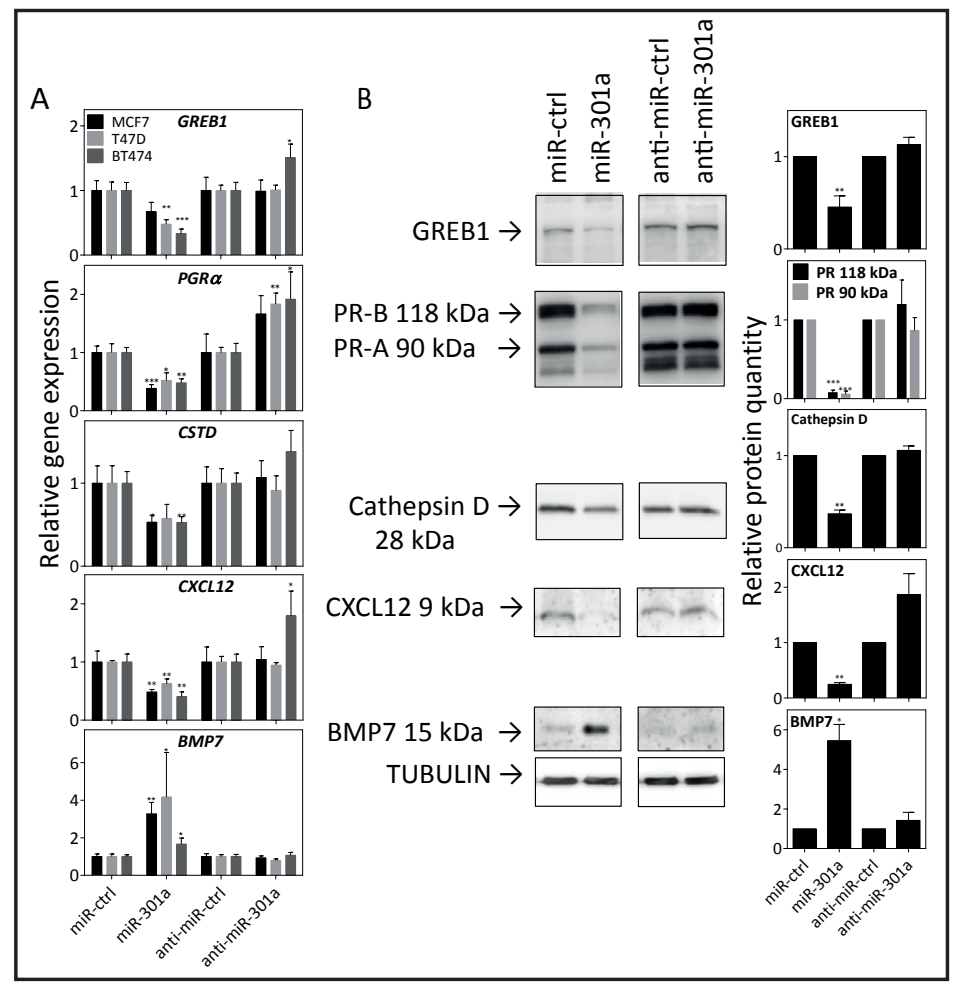

Fig. 3. MiR-301a-3p affects expression of genes and proteins regulated by ER $\alpha$ positively (GREB1, PGRA, CSTD, CXCL12) and negatively (BMP7) in MCF7 cells. A, qRT-PCR showing expression of GREB1, PGRA, CSTD, CXCL12 and BMP7 genes in MCF7, BT474 and T47D cells transfected with miR-301a mimic and miR-301a anti-miR. B, Representative western blots showing expression of GREB1, PR, Cathepsin D, CXCL12 and BMP7 proteins in MCF7 cells transfected with miR-301a mimic and miR-301a anti-miR and densitometry evaluation by image J. Results are represented as mean values \pm S.E.M. $(n=3)$. Statistical significance was calculated using the t-test; ${ }^{*} \mathrm{p}<0.05,{ }^{* *} \mathrm{p}<0.01,{ }^{* * *} \mathrm{p}<0.001$. 
response to 17- $\beta \mathrm{E}_{2}$ in comparison with MCF7 cells transfected with control mimic (Fig. 5A). We did not detect any statistically significant difference between cells transfected with miR-301$a-3 p$ anti-miR and control anti-miR (Fig. $5 \mathrm{~B}$ ), probably reflecting low basal level of miR-301a-3p in MCF7 cells.

The effect of miR-301a-3p mimic was also recapitulated in doxycycline inducible miR-301a-3p MCF7 cell line. After increasing miR-301a level by doxycycline addition, we observed similar decrease in number of cells in response to $17-\beta E_{2}$ (Fig. 5C). No such effect was seen when using MCF7 cells stably transfected with EV (Fig. 5D).

In conclusion, the decrease of ER $\alpha$ by miR-301a-3p overexpression results in a decreased response to $17-\beta \mathrm{E}_{2}$.

MCF7 breast cancer cell line inducibly overexpressing miR-301a grow significantly slower in nude mice, show inhibition of ER signaling and exhibit enrichment of the cancer stemlike cells

To determine the role of miR$301 a-3 p$ in tumor growth, Balb/c nude athymic mice were implanted with slowrelease estradiol pellet and injected subcutaneously with MCF7 cell line expressing miR-301a after induction by doxycycline (Fig. 6A) or with MCF7 cell line containing an empty vector (EV). Both miR-301a and EV clones exhibited similar growth potential without doxycycline induction in vitro as shown by confluency measurement by JULI FL cell analyzer and the changes in proliferation rates are thus not due to inherent properties of selected clones of MCF7 cells (Fig. 6B). The mice were given doxycycline diet and tumor growth was monitored twice a week with ultrasound imaging (Vevo770). Results show that the miR-301a overexpressing group exhibits significant inhibition of tumor growth in comparison with control group injected with cells carrying EV only (Fig. 7A). Both the tumor volume and weight from the miR-301a overexpressing group were significantly decreased in comparison with the control group (Fig. 7B, C).

Moreover, the overexpression of miR-301a in tumors led to a decrease in expression of $\mathrm{ER} \alpha$ and PR proteins, as seen on western blot and also to inhibition of ER signaling measured

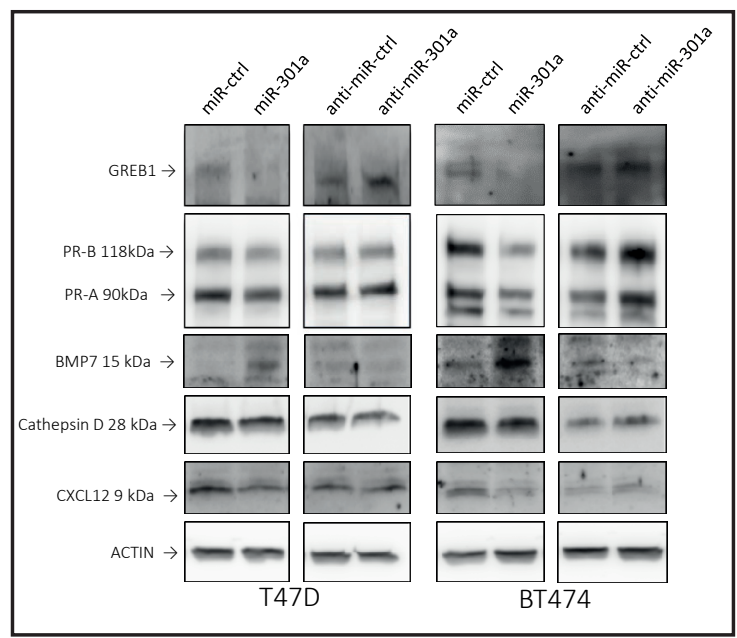

Fig. 4. MiR-301a-3p affects expression of proteins regulated by the ER $\alpha$ signaling in T47D and BT474 cells. Active ER $\alpha$ signaling induces certain proteins (GREB1, PR, CSTD, CXCL12) while others are downregulated (BMP7). Representative western blots showing expression of GREB1, PR, Cathepsin D, CXCL12 and BMP7 proteins in BT474 and T47D cells transfected with miR-301a mimic and miR-301a anti-miR.

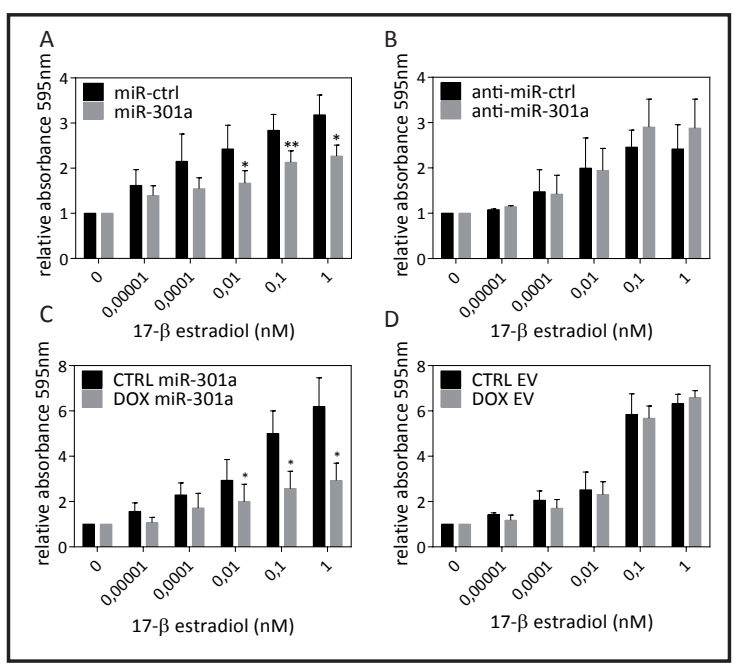

Fig. 5. MiR-301a-3p modulates growth in response to $17 \beta$-estradiol. A, B, C, D Absorbance of crystal violet staining showing effect of $17 \beta$-estradiol on growth of MCF7 cells transfected with miR-301a mimic and miR301a anti-miR and MCF7 cell line inducibly expressing miR-301a or EV after induction by doxycycline. Results are represented as mean values \pm S.E.M. $(n=3)$. Statistical significance was calculated using the t-test; ${ }^{*} \mathrm{p}<0.05,{ }^{* *} \mathrm{p}<0.01$. 
by qRT-PCR. These results are in line with previous in vitro data and in accordance with the fact that MCF7 cells are dependent on estrogen signaling for their proliferation and once this signaling pathway is inhibited they do not grow (Fig. 7D, E). Importantly, we have seen a statistically significant upregulation of genes such as CD44, ALDH1 (Aldehyde dehydrogenase 1), ABCG2 (ATP binding cassette transporter subfamily $G$ member 2), VIM (Vimentin), ZEB1, ZEB2 (Zinc finger E-box-binding homeobox 1, 2), HER2 (Erb-b2 receptor tyrosine kinase 2) and VEGFA (Vascular endothelial growth factor A) which are connected with cancer stem-like cell phenotype, EMT and metastasis (Fig. 7F).

Taken together, these data suggest that increased expression of miR-301a decreases the level of ER $\alpha$ which leads to inhibition of tumor growth of the estrogen-dependent MCF7 cell line in vivo, but on the other hand, it seems to induce an enrichment in the cancer stem-like cell population within the tumor.

\section{MiR-301a-3p expression negatively correlates with ESR1 expression in breast cancer patient samples}

MiR-301a-3p was found to be a crucial oncogene in human breast cancer acting through multiple pathways and mechanisms to promote tumor growth and metastasis $[28,37,38]$. To understand its role in breast cancer, we assessed the miR-301a-3p level in 111 human patient breast cancer samples clinically divided into four groups according to ER, PR and HER2 expression status, which was further confirmed by TaqMan qRT-PCR (data not shown). We found that expression of miR-301a-3p in ER+/PR+/HER2+ samples was 1.5-times lower when compared with the ER-/PR-/HER2+ patients and 2-times lower in comparison with ER-/PR-/HER2- samples (Fig. 8A). Similarly, miR-301a-3p was downregulated by 1.9 fold in ER+/PR+/HER2- samples relative to ER-/PR-/HER2+ samples and by 2.5 -fold relative to ER-/PR-/HER2- samples (Fig. 8A). Unlike ER and PR, the expression of HER2 has no statistically significant correlation with the expression of miR-301a-3p in studied samples (Fig. 8A). On the other hand, a statistically significant negative correlation between the miR301a-3p and ESR1 level was observed (Fig. 8B).

Collectively, observed results show a negative correlation between the expression of miR-301a-3p and ER/PR status in breast cancer patient samples, suggesting that higher expression of miR-301a-3p is connected with lower expression of ESR1.

\section{Discussion}

MiR-301a-3p has been shown as a negative prognostic marker in many human cancers since cells with high level of miR-301a-3p display higher metastatic potential [38, 39]. However, its role in ER-positive breast cancer has not been elucidated yet. Breast cancer is the most frequent malignancy in women worldwide. More than half of the patients are diagnosed with the estrogen positive cancer which has good prognosis and is often treated with the anti-estrogenic drug, tamoxifen. Although the drug is efficient and well tolerated, 
Fig. 7. MiR-301a-3p reduce tumor growth and inhibit ER signaling in vivo A, Growth of MCF7 cell line inducibly expressing miR-301a after doxycycline addition in Balb/c nude mice (injected $2 \times 10^{6}$ cells per animal) which were implanted with slow-release estradiol pellet, given doxycycline diet; tumor volume was monitored twice a week and evaluated by ultrasound imaging instrument Vevo 770. B, Photographs showing representative tumors formed C, Tumor weight at the end of experiment D, Western blot showing expression of ER $\alpha$ and PR protein in tumor samples in control or miR-301a-3p overexpressing tumors and corresponding densitometry evaluation by image J. E, F, qRT-PCR showing expression of miR-301a-3p and GREB1, PGRA, CSTD, CXCL12, $B M P 7, C D 44, A L D H 1, A B C G 2$, VEGFA, VIM, ZEB1, ZEB2 and HER2 genes in control or miR301a-3p overexpressing tumors. Results are represented as mean values \pm S.E.M. $(n=7)$. Statistical significance was

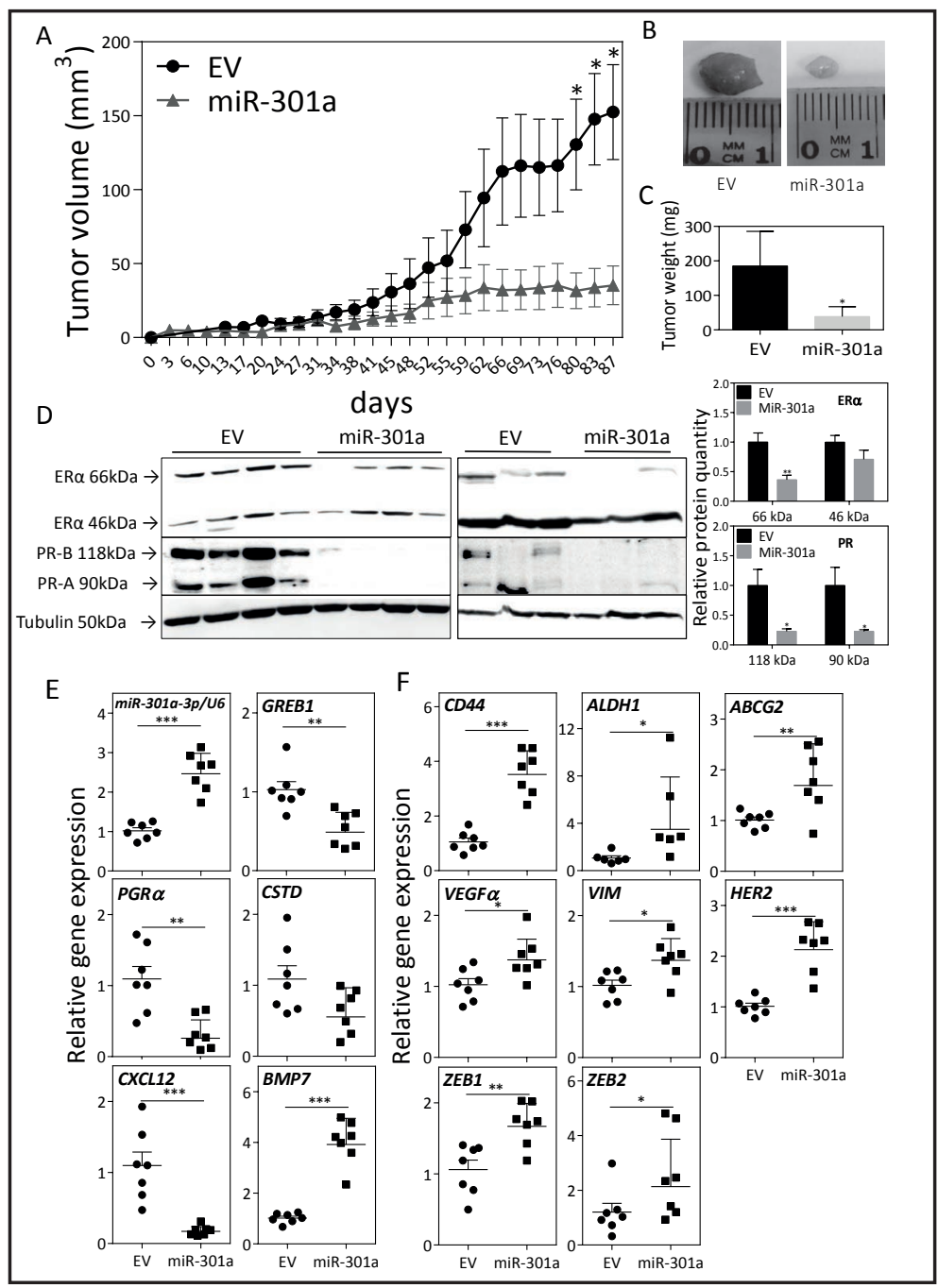
calculated using the t-test; * $\mathrm{p}<0.05,{ }^{* *} \mathrm{p}<0.01,{ }^{* * *} \mathrm{p}<0.001$.

Fig. 8. MiR-301a-3p and ESR1 expression inversely correlate in human breast cancer. A, qRT-PCR showing level of miR-301a-3p in breast cancer tissues divided according to their ER, PR and HER2 status into 4 groups. B, Pearson's correlation scatter plot of the correlation between ESR1 gene and miR-301a-3p in breast cancer tissues. Results are represented as mean values \pm S.E.M. Statistical significance was calculated using

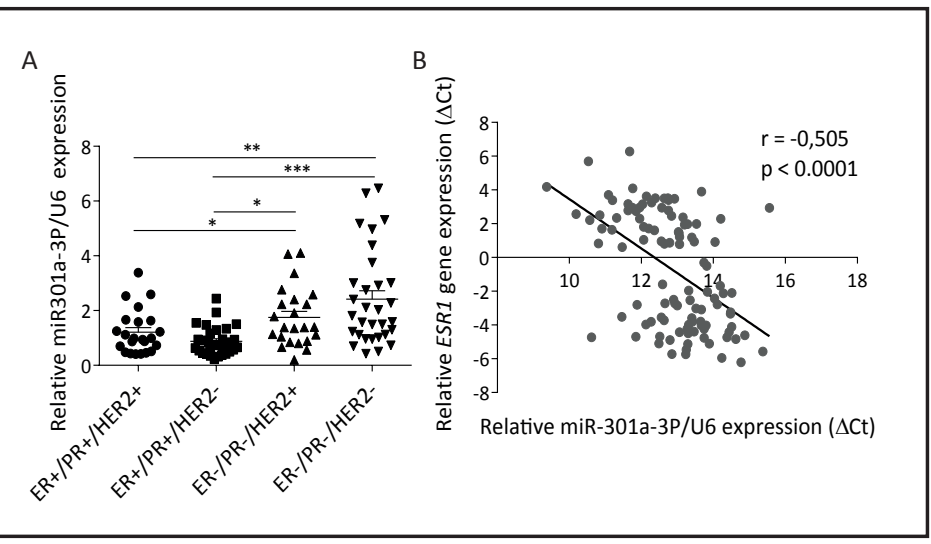
the t-test; ${ }^{*} \mathrm{p}<0.05, * * \mathrm{p}<0.01, * * *$ $\mathrm{p}<0.001$.

30-40\% of patients relapse with metastasis which do not response to endocrine therapy due to loss of ER $[40,41]$. The transition from ER-positive to ER-negative breast cancer 
thus represents a very important clinical problem and therefore finding markers predicting estrogen independence is of high importance.

ESR1 mRNA has a long 3'UTR region of about $4.3 \mathrm{~kb}$ bearing many evolutionarily conserved miRNA target sites, and several miRNAs such as miR-22 [42], -206 [43, 44], -145 [45] have already been reported to regulate ER $\alpha$ protein expression. In this report, we analyzed the cis regulatory sequences in the 3'UTR of ESR1 gene mRNA and identified 2 seed sequences, which are able to bind miR-301a-3p. We have further generated a reporter vector where Cypridina luciferase gene is coupled to the 3'UTR of ESR1 and demonstrated that deletion of these two sites results in higher expression of the luciferase, thus confirming the role of these two sites in the negative regulation of the ER $\alpha$ protein expression. Interestingly, site deletion showed that the first site closer to the end of translation is a preferred binding site for miR-301a-3p as its deletion resulted in identical phenotype to the deletion of both binding sites. Yet, the deletion of the second site also led to an increase in reporter luciferase expression suggesting that this site can be utilized by miR-301a-3p as well. We showed that miR-301a-3p downregulates ESR1 mRNA and ER $\alpha$ protein level and, more importantly, inhibits the canonical estrogen signaling pathway in MCF7, T47D and BT474 breast cancer cell lines. This leads to lower expression of genes positively regulated by ER $\alpha$ (PGRA, GREB1, CXCL12, CSTD) and to induction of genes negatively regulated by ER $\alpha$ (BMP7). Moreover, we demonstrated that overexpression of miR-301a-3p caused inhibition of proliferation of estrogen-dependent MCF7 cells in vitro and suppressed the growth of miR-301a-3p overexpressing MCF7 tumors in nude mice. These results further confirmed that ESR1 is a direct target of miR-301a-3p in vitro and in vivo and are in line with already published results referring to miRNAs targeting $\mathrm{ER} \alpha[44,45]$.

We did not detect any significant changes when using miR-301a-3p anti-miR with exception of BT474 cells that express high levels of miR-301a-3p. This suggests that the effect is predominantly caused by the translational inhibition of ESR 1 mRNA and could be detected only in cells with higher endogenous miR-301a-3p levels where the anti-miR treatment is more effective. An alternative explanation is that ESR1 mRNA is relatively abundant and contains long 3'UTR with many other regulatory miRNA sites [46]. In that situation, the impact of miR-301a-3p anti-miR could be limited by low expression of miR-301a-3P in comparison with other abundant and non-inhibited regulatory miRNAs as suggested by Androsavich and Chau [47].

Interestingly, we detected an increase in the expression of HER2 gene in miR-301a-3p overexpressing tumors. Our data are in line with observation that HER2 is upregulated in tamoxifen-resistant MCF7 cells with decreased ER $\alpha$ signaling [48] and also in breast cancer stem-like cells [49]. Apart from HER2, we observed upregulation of other markers related to cancer stem-like cells, EMT and metastatic phenotype such as CD44, ALDH1, ABCG2, $V I M, Z E B 1, Z E B 2$ and VEGFA in cells from miR-301a-3p overexpressing tumors. The cancer stem-like cell properties of miR-301a-3p overexpressing cells were further confirmed by analysis of mammospheres, the in vitro model of cancer stem-like cells [33], which expressed dramatically higher level of miR-301a-3p together with significantly lower ER $\alpha$ protein level, accompanied by inhibition of ER $\alpha$ targets GREB1 and PR. Furthermore, the other ER $\alpha-$ regulating miRNAs such as miR-22, -145 and -206 were not significantly and consistently elevated in sphere samples (data not shown). Given that Shi et al [28]. showed that miR$301 a-3 p$ renders breast cancer nonresponsive to the anti-estrogenic drug tamoxifen, we hypothesized that upregulation of miR-301a-3p may represent a feasible mechanism contributing to the phenotypical shift of primarily ER $\alpha$ dependent cells toward tumor cells relying on other proliferative signals. More importantly, since miR-301a-3p overexpressing cells acquire properties of cancer stem-like cells, which are highly invasive and resistant to treatment [50-52], they might represent the subpopulation that survives endocrine therapy and gives rise to relapsing metastasis.

In order to define whether the expression of miR-301a-3p in the samples of real human breast tumors is correlated with ER $\alpha$ expression, we analyzed primary human breast cancer biopsies and found significantly higher miR-301a-3p level in patient samples that were ER-

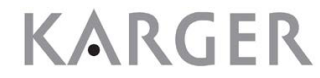


negative. Similarly, we have detected a significant negative correlation between miR-301a-3p expression and ESR1 expression. Since miR-301a-3p is able to regulate ER $\alpha$ signaling it might serve as a biomarker of breast cancer prognosis and response to endocrine treatment. Our findings are thus in line with findings that higher expression of miR-301a-3p is significantly associated with larger tumor size and lymph node metastases in triple negative breast cancer [37]. Importantly, as miR-301a-3p also regulates other signaling pathways that are important in the progression of breast cancer such as PTEN/Akt or NFKB signaling [28, 38, 53 ] it can be utilized as a general marker of poor prognosis.

In summary, our study provides functional evidence that miR-301a-3p is able to downregulate ER signaling in the ER positive breast cancer cells in vitro as well as in vivo, thus forcing them to become estrogen-independent with high selection pressure to activate alternative survival/pro-proliferative pathways in order to proliferate. The transition of estrogen-dependent cancer into the estrogen-independent cancer is one of the crucial steps in carcinogenesis and together with documented effects of miR-301a-3p on cancer motility and metastasis, our results suggest that miR-301a-3p might be used as a marker of poor patient prognosis and higher chance to become hormone-insensitive and resistant to tamoxifen.

\section{Acknowledgements}

SL and JT developed the ideas and drafted the manuscripts. SL, JB, JT, DV, MV and VB conducted experiments and contributed to analysis of data. All authors contributed to revise the manuscript and approved the final version for publication.

This work was supported by the Czech Science Foundation grant 13-28830S to J.T., the Ministry of Health of the Czech Republic grant no. AZV 17-28470A to P.S., the Kellner Family Foundation grant to J.T. and the Grant Agency of Charles University Grant no. GAUK112315 to S.L. It was also funded by the Ministry of Education, Youth and Sports of CR within the LQ1604 National Sustainability Program II (Project BIOCEV-FAR) to J.T. and L01503 to P.S., by the project „BIOCEV“(CZ.1.05/1.1.00/02.0109) and by the Czech Academy of Sciences (RVO:86652036).

The ethics approval statements for animal work were approved by Czech Academy of Sciences and conducted in accordance with Czech Council guidelines for the Care and Use of Animals in Research and Teaching. Written informed consent was obtained from all participant and the study was approved by the Ethical Commission of the National Institute of Public Health in Prague.

\section{Disclosure Statement}

The authors declare that they have no conflicts of interest.

\section{References}

Jemal A, Bray F, Ferlay J: Global Cancer Statistics. CA. Cancer J Clin 2011;61:69-90.

Siegel RL, Miller KD, Jemal A: Cancer statistics, 2017. CA. Cancer J Clin 2017;67:7-30.

Kennecke H, Yerushalmi R, Woods R, Cheang MCU, Voduc D, Speers CH, Nielsen TO, Gelmon K: Metastatic behavior of breast cancer subtypes. J Clin Oncol 2010;28:3271-3277.

4 Onitilo AA, Engel JM, Greenlee RT, Mukesh BN: Breast cancer subtypes based on ER/PR and Her2 expression: comparison of clinicopathologic features and survival. Clin Med Res Marshfield Clinic 2009;7:4-13.

5 Huang R, Han J, Liang X, Sun S, Jiang Y, Xia B, Niu M, Li D, Zhang J, Wang S, Wei W, Liu Q, Zheng W, Zhang G, Song Y, Panga D: Androgen Receptor Expression and Bicalutamide Antagonize Androgen Receptor Inhibit $\beta$-Catenin Transcription Complex in Estrogen Receptor-Negative Breast Cancer. Cell Physiol Biochem 2017;43:2212-2225.

6 hen Y, Yang F, Zhang W, Song W, Liu Y, Guan X: The Androgen Receptor Promotes Cellular Proliferation by Suppression of G-Protein Coupled Estrogen Receptor Signaling in Triple-Negative Breast Cancer. Cell Physiol Biochem 2017;43:2047-2061. 


\section{Cellular Physiology Cell Physiol Biochem 2018;46:2601-2615 and Biochemistry Published online: May 14, $2018 \quad \begin{aligned} & \text { DOI: 10.1159/000489687 } \\ & \begin{array}{l}\text { (c) } 2018 \text { The Author(s). Published by S. Karger AG, Basel } \\ \text { www.karger.com/cpb }\end{array}\end{aligned}$}

Lettlova et al.: miR-301a-3p Suppresses Estrogen Signaling

7 Nilsson S, Mäkelä S, Treuter E, Tujague M, Thomsen J, Andersson G, Enmark E, Pettersson K, Warner M, Gustafsson JA: Mechanisms of estrogen action. Physiol Rev 2001;81:1535-1565.

8 Stingl J: Estrogen and Progesterone in Normal Mammary Gland Development and in Cancer. Horm Cancer 2011;2:85-90.

-9 Huang B, Omoto Y, Iwase H, Yamashita H, Toyama T, Coombes RC, Filipovic A, Warner M, Gustafsson JA: Differential expression of estrogen receptor $\alpha, \beta 1$, and $\beta 2$ in lobular and ductal breast cancer. Proc Natl Acad Sci U S A 2014;111:1933-1938.

10 Wei XL, Dou XW, Bai JW, Luo XR, Qiu SQ Xi DD, Huang WH, Du CW, Man K, Zhang GJ: ER $\alpha$ inhibits epithelialmesenchymal transition by suppressing Bmi1 in breast cancer. Oncotarget 2015;6:21704-21717.

11 Ye Y, Xiao Y, Wang W, Yearsley K, Gao JX, Shetuni B, Barsky SH: ER $\alpha$ signaling through slug regulates E-cadherin and EMT. Oncogene 2010;29:1451-1462.

12 McDonnell DP, Wardell SE, Norris JD: Oral Selective Estrogen Receptor Downregulators (SERDs), a Breakthrough Endocrine Therapy for Breast Cancer. J Med Chem 2015;58:4883-4887.

$\checkmark 13$ Azariadis K, Kiagiadaki F, Pelekanou V, Bempi V, Alexakis K, Kampa M, Tsapis A, Castanas E, Notas G: Androgen Triggers the Pro-Migratory CXCL12/CXCR4 Axis in AR-Positive Breast Cancer Cell Lines: Underlying Mechanism and Possible Implications for the Use of Aromatase Inhibitors in Breast Cancer. Cell Physiol Biochem 2017;44:66-84.

14 Early Breast Cancer Trialists' Collaborative Group (EBCTCG): Effects of chemotherapy and hormonal therapy for early breast cancer on recurrence and 15-year survival: an overview of the randomised trials. Lancet 2005;365:1687-717.

15 Early Breast Cancer Trialists' Collaborative Group: Tamoxifen for early breast cancer: an overview of the randomised trials. Lancet 1998;351:1451-1467.

16 Giacinti L, Claudio PP, Lopez M, Giordano A: Epigenetic Information and Estrogen Receptor Alpha Expression in Breast Cancer. Oncologist 2006;11:1-8.

$\checkmark 17$ Tang Z, Treilleux I, Brown M: A transcriptional enhancer required for the differential expression of the human estrogen receptor in breast cancers. Mol Cell Biol 1997;17:1274-1280.

18 Karnik PS, Kulkarni S, Liu XP, Budd GT, Bukowski RM: Estrogen receptor mutations in tamoxifen-resistant breast cancer. Cancer Res 1994;54:349-353.

19 Shi L, Dong B, Li Z, Lu Y, Ouyang T, Li J, Wang T, Fan Z, Fan T, Lin B, Wang Z, Xie Y: Expression of ER- $\alpha 36$, a Novel Variant of Estrogen Receptor $\alpha$, and Resistance to Tamoxifen Treatment in Breast Cancer. J Clin Oncol 2009;27:3423-3429.

20 Le Romancer M, Poulard C, Cohen P, Sentis S, Renoir JM, Corbo L: Cracking the estrogen receptor's posttranslational code in breast tumors. Endocr Rev 2011;32:597-622.

-21 Iorio M V, Ferracin M, Liu CG, Veronese A, Spizzo R, Sabbioni S, Magri E, Pedriali M, Fabbri M, Campiglio M, Ménard S, Palazzo JP, Rosenberg A, Musiani P, Volinia S, Nenci I, Calin GA, Querzoli P, Negrini M, Croce CM: MicroRNA Gene Expression Deregulation in Human Breast Cancer. Cancer Res 2005;65:7065-7070.

-22 Gregory RI, Chendrimada TP, Cooch N, Shiekhattar R: Human RISC couples microRNA biogenesis and posttranscriptional gene silencing. Cell 2005;123:631-640.

23 Iorio M V, Croce CM: microRNA involvement in human cancer. Carcinogenesis 2012;33:1126-1133.

24 Chen Z, Chen LY, Dai HY, Wang P, Gao S, Wang K: miR-301a promotes pancreatic cancer cell proliferation by directly inhibiting Bim expression. J Cell Biochem 2012;113:3229-3235.

-25 Xu XD, He XJ, Tao HQ, Zhang W, Wang YY, Ye ZY, Zhao ZS: Abnormal expression of miR-301a in gastric cancer associated with progression and poor prognosis. J Surg Oncol 2013;108:197-202.

26 Zhou P, Chang R, Jiang W, Wu L, Wu K, Wang Z: MiR-301a is a candidate oncogene that targets the homeobox gene gax in human hepatocellular carcinoma. Dig Dis Sci 2012;57:1171-1180.

27 Fang Y, Sun B, Xiang J, Chen Z: MiR-301a Promotes Colorectal Cancer Cell Growth and Invasion by Directly Targeting SOCS6. Cell Physiol Biochem 2015;35:227-236.

28 Shi W, Gerster K, Alajez NM, Tsang J, Waldron L, Pintilie M, Hui AB,Sykes J,P’ng C, Miller N, McCready D, Fyles A, Liu FF: MicroRNA-301 mediates proliferation and invasion in human breast cancer. Cancer Res 2011;71:2926-2937.

-29 Brynychová V, Hlaváč V, Ehrlichová M, Václavíková R, Pecha V, Trnková M, Wald M, Mrhalová M, Kubáčková K, Pikus T, Kodet R, Kovář J, Souček P: Importance of transcript levels of caspase-2 isoforms S and L for breast carcinoma progression. Future Oncol 2013;9:427-438.

30 Tavassoli FA, Devilee P: Pathology and genetics: tumours of the breast and female genital organs. 4th ed Lyon: IARC Press, 2003.

-31 Borgna S, Armellin M, di Gennaro A, Maestro R, Santarosa M: Mesenchymal traits are selected along with stem features in breast cancer cells grown as mammospheres. Cell Cycle 2014;11:4242-4251. 


\section{Cellular Physiology Cell Physiol Biochem 2018;46:2601-2615 and Biochemistry Published online: May 14, $2018 \quad \begin{aligned} & \text { DOI: 10.1159/000489687 } 2018 \text { The Author(s). Published by S. Karger AG, Basel } \\ & \text { www.karger.com/cpb }\end{aligned}$ \\ Lettlova et al.: miR-301a-3p Suppresses Estrogen Signaling}

32 Nam RK, Benatar T, Wallis CJD, Amemiya Y, Yang W, Garbens A, Naeim M, Sherman C, Sugar L, Seth A: MiR-301a regulates E-cadherin expression and is predictive of prostate cancer recurrence. Prostate 2016;76:869-884.

33 Rychtarcikova Z, Lettlova S, Tomkova V, Korenkova V, Langerova L, Simonova E, Zjablovskaja P, AlberichJorda M, Neuzil J, Truksa J: Tumor-initiating cells of breast and prostate origin show alterations in the expression of genes related to iron metabolism. Oncotarget 2017;8:6376-6398.

-34 Guttilla IK, Phoenix KN, Hong X, Tirnauer JS, Claffey KP, White BA: Prolonged mammosphere culture of MCF-7 cells induces an EMT and repression of the estrogen receptor by microRNAs. Breast Cancer Res Treat 2012;132:75-85.

35 Lin CY, Ström A, Vega VB, Kong SL, Yeo AL, Thomsen JS, Chan WC, Doray B, Bangarusamy DK, Ramasamy A,Vergara LA, Tang S, Chong A, Bajic VB, Miller LD, Gustafsson JA, Liu ET: Discovery of estrogen receptor alpha target genes and response elements in breast tumor cells. Genome Biol 2004;5:R66.

36 Feoktistova M, Geserick P, Leverkus M: Crystal Violet Assay for Determining Viability of Cultured Cells. Cold Spring Harb Protoc 2016;2016:pdb.prot087379.

-37 Yu H, Li H, Qian H, Jiao X, Zhu X, Jiang X, Dai G, Huang J: Upregulation of miR-301a correlates with poor prognosis in triple-negative breast cancer. Med Oncol 2014;31:283.

-38 Ma F, Zhang J, Zhong L, Wang L, Liu Y, Wang Y, Peng L, Guo B: Upregulated microRNA-301a in breast cancer promotes tumor metastasis by targeting PTEN and activating Wnt/ $\beta$-catenin signaling. Gene 2014;535:191-197.

39 Cui L, Li Y, Lv X, Li J, Wang X, Lei Z, Li X: Expression of MicroRNA-301a and its Functional Roles in Malignant Melanoma. Cell Physiol Biochem 2016;40:230-44.

40 Kuukasjärvi T, Kononen J, Helin H, Holli K, Isola J: Loss of estrogen receptor in recurrent breast cancer is associated with poor response to endocrine therapy. J Clin Oncol 1996;14:2584-2589.

41 Holdaway IM, Bowditch JV: Variation in receptor status between primary and metastatic breast cancer. Cancer 1983;52:479-485.

-42 Pandey D, Picard D: miR-22 Inhibits Estrogen Signaling by Directly Targeting the Estrogen Receptor $\alpha$ mRNA. Mol Cell Biol 2009;29:3783-3790.

43 Adams BD, Furneaux H, White BA: The Micro-Ribonucleic Acid (miRNA) miR-206 Targets the Human Estrogen Receptor- $\alpha(E R \alpha)$ and Represses ER $\alpha$ Messenger RNA and Protein Expression in Breast Cancer Cell Lines. Mol Endocrinol 2007;21:1132-1147.

-44 Kondo N, Toyama T, Sugiura H, Fujii Y, Yamashita H: miR-206 Expression Is Down-regulated in Estrogen Receptor $\alpha$-Positive Human Breast Cancer. Cancer Res 2008;68:5004-5008.

45 Spizzo R, Nicoloso MS, Lupini L, Lu Y, Fogarty J, Rossi S, Zagatti B, Fabbri M, Veronese A, Liu X, Davuluri R, Croce CM, Mills G, Negrini M, Calin GA: miR-145 participates with TP53 in a death-promoting regulatory loop and targets estrogen receptor- $\alpha$ in human breast cancer cells. Cell Death Differ 2010;17:246-254.

-46 Leivonen SK, Mäkelä R, Östling P, Kohonen P, Haapa-Paananen S, Kleivi K, Enerly E, Aakula A, Hellström K, Sahlberg N, Kristensen VN, Børresen-Dale AL, Saviranta P, Perälä M, Kallioniemi O: Protein lysate microarray analysis to identify microRNAs regulating estrogen receptor signaling in breast cancer cell lines. Oncogene 2009;28:3926-3936.

47 Androsavich JR, Chau BN: Non-inhibited miRNAs shape the cellular response to anti-miR. Nucleic Acids Res 2014;42:6945-6955.

-48 Gee JM, Robertson JF, Gutteridge E, Ellis IO, Pinder SE, Rubini M, Nicholson RI: Epidermal growth factor receptor/HER2/insulin-like growth factor receptor signalling and oestrogen receptor activity in clinical breast cancer. Endocr Relat Cancer 2005;12:S99-111.

49 Korkaya H, Paulson A, Iovino F, Wicha MS: HER2 regulates the mammary stem/progenitor cell population driving tumorigenesis and invasion. Oncogene 2008;27:6120-6130.

-50 Liu S, Cong Y, Wang D, Sun Y, Deng L, Liu Y, Martin-Trevino R, Shang L, McDermott SP, Landis MD, Hong S, Adams A, D'Angelo R, Ginestier C, Charafe-Jauffret E, Clouthier SG, Birnbaum D, Wong ST, Zhan M, Chang JC, Wicha MS: Breast Cancer Stem Cells Transition between Epithelial and Mesenchymal States Reflective of their Normal Counterparts. Stem Cell Reports 2014;2:78-91.

51 Dean M: ABC transporters, drug resistance, and cancer stem cells. J. Mammary Gland Biol. Neoplasia 2009;14:3-9.

52 Nassar D, Blanpain C: Cancer Stem Cells: Basic Concepts and Therapeutic Implications. Annu. Rev. Pathol Mech Dis 2016;11:47-76.

53 Lu Z, Li Y, Takwi A, Li B, Zhang J, Conklin DJ, Young KH, Martin R, Li Y: miR-301a as an NF- $\kappa$ B activator in pancreatic cancer cells. EMBO J 2011;30:57-67. 